\title{
Editorial: Diagnostic and Proof Load Tests on Bridges
}

\author{
Eva O. L. Lantsoght ${ }^{1,2 *}$ \\ ${ }^{1}$ Politécnico, Universidad San Francisco de Quito, Quito, Ecuador, ${ }^{2}$ Concrete Structures, Department of Engineering \\ Structures, Civil Engineering and Geosciences, Delft University of Technology, Delft, Netherlands
}

Keywords: proof load test, diagnostic load test, Editorial, load distribution, shear, flexural strength

\section{Editorial on the Research Topic}

\section{Diagnostic and Proof Load Tests on Bridges}

The load testing of bridges is a practice as old as bridge engineering. In the past, load testing was used when a new bridge was built and was a means of demonstrating that the structure was safe for the traveling public. Over time, engineers have developed different practices for load testing, many of which follow on from these traditions as they are based on practical experience, a practice that has influenced current codes and guidelines for load testing. These codes and guidelines use limits based on experience, which may differ across countries, and which may not directly be related to the philosophy of the safety of these design codes. Procedures for the field testing of new and existing bridges have been developed, and over time the range of applications of load tests have grown significantly from simply demonstrating that a bridge is safe for use to determining particular aspects of structural behavior, such as the contribution of non-structural elements (barriers, curbs, etc.) to the overall stiffness of the structure, or transverse load distribution.

There are two main types of load test, diagnostic load tests and proof load tests. Diagnostic load

Edited by:

Xin Ruan,

Tongji University, China

Reviewed by:

David De Leon,

Universidad Autónoma del Estado de

México, Mexico

*Correspondence:

Eva O. L. Lantsoght

elantsoght@usfq.edu.ec

Specialty section:

This article was submitted to

Bridge Engineering

a section of the journal

Frontiers in Built Environment

Received: 23 July 2020

Accepted: 14 September 2020

Published: 15 October 2020

Citation:

Lantsoght EOL (2020) Editorial:

Diagnostic and Proof Load Tests on

Bridges.

Front. Built Environ. 6:586704.

doi: 10.3389/fbuil.2020.586704 testing is used to evaluate and update the analytical models for the design and assessment of bridges. For new bridges, diagnostic tests can be used to demonstrate that the bridge behaves as designed. For existing bridges, diagnostic tests can be used to update the model that is employed for some sort of decision-making, for example determining the load rating of the bridge, load permits for special loads. Proof load testing is used to demonstrate that a given bridge can safely carry the loads prescribed by the governing code or a specification. A load corresponding to the load combination prescribed by the governing code or specification is applied to the bridge. If the bridge can carry this load without signs of distress, the test is considered to show that the bridge can fulfill specified load requirements.

This Research Topic includes a number of case studies, examples of the load testing of bridges, and discusses potential ways of expanding knowledge of the subject. One of the ways in which load testing has evolved is in terms of the tools that are used to interpret optimal field test results. A contribution by Commander shows the evolution of diagnostic load testing in the US. This article shows how the lines between field testing, structural health monitoring, and non-destructive testing have been blurred, and how these techniques are becoming more and more intertwined. The author illustrates how a bridge engineer can select the right tools in response to test objectives and discusses emerging technologies. From a European perspective, a study by Olaszek and Casas offers practical advice for static and dynamic load tests. This article examines the factors that can result in errors in interpreting test results compared to target values or values derived from a numerical model. Such errors can lead to errors in bridge assessment, and ultimately, wrong decisions.

Another contribution by Shahsavari et al. considers the synergy between structural health monitoring and load testing using the Memorial Bridge as a case study. 
This bridge has a structural health monitoring system in place, and the study examines the bridge using numerical models. A load test was carried out to calibrate the finite element models and to define post-processing and decision-making tools related to structural performance. Al-Khateeb et al. explore the combination of structural health monitoring and load testing based on the Indian River Inlet Bridge, which has been subject to six load tests since 2012. The authors focus on how a structural health monitoring system can be valuable for repeat diagnostic load tests, giving insights into bridge performance. The authors indicate how repeated diagnostic load tests form an integral aspect of the bridge operation and maintenance strategy. In another case study, Duvnjak et al. discuss a damaged steel railway bridge in Croatia, which was monitored during strengthening works. In this example load testing was used to update the finite element of the bridge, to evaluate its ability to carry the design loads, and to determine the dynamic parameters of the structure.

In recent years load testing is often combined with finite element modeling. Wolert et al. detail a case study of a 100year-old reinforced concrete flat slab bridge, of which no plans, reinforcement details, or records from the time of construction are available. The contribution shows how the field test results were used to develop a field-verified finite element model of the structure, after which the structure could be load rated. In another article, Lantsoght, de Boer et al. show the advantages and challenges associated with combining proof load testing results and non-linear finite element results, based on the case study of Viaduct De Beek. When compared to linear finite element modeling, the presented method requires more time and effort but may result in a sharper assessment and avoid unnecessary strengthening actions.

Nowadays, load tests on new bridges are not required before they open. However, for bridges using novel materials or structural systems, it is good practice to conduct a load test to verify its performance upon completion of construction. Alahmari et al. present a case study that involved the diagnostic and proof load testing of a prestressed concrete bridge using high performance concrete girders in span 2 and locally developed ultra-high performance concrete girders in span 1 . These field tests allowed for a direct comparison between the high performance concrete girders and ultra-high performance concrete girders. Additionally, the test results provided a baseline of performance, and repeated tests can be used to study durability and possible changes in load distribution over time. Hernandez and Myers report another case study in which diagnostic load testing was conducted on a bridge with self-consolidating concrete (SCC) girders and high-strength self-consolidating concrete girders. The focus of the study is the transverse load distribution, and the results from the field test are compared to distribution factors obtained with a finite element model and AASHTO LRFD Bridge Design Specifications. The authors show that the distribution factors from AASHTO LRFD result in larger values than the field test and that no difference in behavior can be observed between the SCC and conventional concrete members.

Wenner et al. show the results of load testing of the Itz Valley Railway Viaduct. The goal of this case study was to determine the longitudinal pier stiffness, to show whether load testing can also be used to learn more about the properties of the substructure.
For this purpose, diagnostic load tests and breaking tests were carried out, and the results of these experiments were compared to numerical predictions. Diagnostic load tests can be used to identify composite action, as demonstrated by the three case studies presented in Yarnold et al.. In many existing bridges the level of composite action may be unknown, and the authors explored how load testing can be used to identify composite action, discussing the advantages and disadvantages of these diagnostic load tests. Dong et al. show a case study of a concrete highway bridge, where a static load test was used to determine the live load distribution factor and the load rating factor, and the characteristics of the model were determined through the use of different truck-load and speed cases. Zhou and Guzda show a case study of proof load testing on a prestressed girder bridge, where uncertainties arose with regard to the shear capacity of the dapped ends of the prestressed girders.

Over time, the importance of measurements during load testing has also increased. While traditional load testing may be limited to a single deflection measurement, one can now find reports from load tests with more elaborate instrumentation, which can address a number of elements of structural behavior. When undertaking proof load testing, the importance of measurements lies is connected to verifying the stop criteria, as shown by Lantsoght, Yang et al.. This research study examines current stop criteria for proof load tests for flexure, and derives new stop criteria for strain and crack width to avoid a flexural failure during a proof load test. The proposed stop criteria were verified by field tests and the results from laboratory experiments.

To align the safety philosophy of design codes with the practice of bridge load testing, concepts of structural reliability are combined with load testing. Schmidt et al. show how concepts of structural reliability can be used to develop an approach to probabilistic decision analysis. This approach encompasses two parts: (1) providing a basis for decision-making during a proof load test to ensure a safe and efficient execution; and (2) identifying efficient strategies for bridge reclassification, accounting for the available information obtained for load testing, monitoring, and modeling.

The papers in this Research Topic present practical insights into the current state of bridge load testing and show how this practice has evolved.

\section{AUTHOR CONTRIBUTIONS}

The author confirms being the sole contributor of this work and has approved it for publication.

\section{ACKNOWLEDGMENTS}

I am grateful for the contributions of my topic co-editor, Prof. Catbas to the success of this collection of articles. I appreciate all contributions of the authors and sincerely value the time and effort of the authors in preparing these articles. I would also like to thank all review editors who contributed to this Research Topic, as well as the associate editors who helped managing the manuscripts. Finally, I would like to thank Prof. Casas for 
suggesting this Research Topic and his advice and guidance during the development of this collection of articles.

Conflict of Interest: The author declares that the research was conducted in the absence of any commercial or financial relationships that could be construed as a potential conflict of interest.
Copyright $\odot 2020$ Lantsoght. This is an open-access article distributed under the terms of the Creative Commons Attribution License (CC BY). The use, distribution or reproduction in other forums is permitted, provided the original author $(s)$ and the copyright owner(s) are credited and that the original publication in this journal is cited, in accordance with accepted academic practice. No use, distribution or reproduction is permitted which does not comply with these terms. 